\title{
Combatting the Menace of Youth Restiveness in Nigeria Through Citizenship Education
}

\author{
MOHAMMED MUSTAPHA \\ General Studies Education Department, Federal College of Education, Okene-Kogi State
}

\begin{abstract}
Peaceful coexistence, tolerance, perseverance and security are looking more elusive in Nigeria today due to the activities of the youth. The rate of involvement of youth in violent crimes is giving the government and every patriotic Nigerians serious concern. The common maxim that the youth are the leaders of tomorrow seems more elusive than real. The youth are at the centre of all the violent crimes in Nigeria. The writer identifies poor family upbringing, bad governance and unemployment are the major causes of restiveness in Nigeria. The paper examines citizenship education as a veritable means of curbing the menace and recommend job creation, proactive value reorientation and public enlightenment as a way out of the wood.
\end{abstract}

Keywords: Youth; Youth Restiveness; Citizen; Citizenship Education

DOI: $10.7176 / \mathrm{JEP} / 10-8-01$

Publication date:March $31^{\text {st }} 2019$

\section{Introduction}

Youth are commonly considered as the trustees of society they are additionally presented as having a critical stake in the survival of any society. Youthful age is a vital period throughout everyday life and accompany overpowering difficulties which require watchful and legitimate course to help the adolescent settle on appropriate choices that will influence both the society and their own lives. Accordingly, they should be made to regard the standards of any society through meaningful introduction to imperative education in citizenship if a society is to be kept up and supported as far as improvement.

Youth restiveness in Nigeria has been a noticeable issue as of late. There has been an increment in the event of demonstrations of viciousness and wilderness, including things like kidnapping of important personalities and foreign oil workers, as well as oil bunkering, arms insurrection, cultism, and so forth., particularly in the Niger Delta area. Nevertheless, youth restiveness is nothing new. Different types of youth restiveness that are economically, politically, or religiously motivated have existed for quite a while. Elegbeleye (2005) strikingly catches the milestone instances of youth restiveness in Nigeria.

Nigeria today is experiencing high rate of insecurity, which can be attributed to the inability of various level of government to adopt conventional approach to solving restiveness as a destabilising phenomenon. The Boko Haram crisis in the North, the Fulani herdsmen ravaging the country, inter tribal crises, agitation for secession (Biafra), destruction of lives and properties, armed robbery, drug abuse and trafficking, heinous crimes are mostly being carried out by youth. These vices prevail and continue to flourish.

Youngsters everywhere throughout the world are an indispensable and essential fragment of the society in which they live. A diligent, focused, and well-behaved youth can make a splendid future for any country. Then again, an uncivilized, liberal, and rebellious youth is an incredible danger to a country's tranquillity and security.

\section{Conceptual considerations}

The concept "citizenship education" is a combination of two terms namely: "citizenship" and "education", it is pertinent to know the respective meaning of the terms "citizen", "citizenship" and "education". In the western perspective, the term citizen is used to refer to a person who has full rights as a member of a society, nation or country, either by birth or by being granted such rights. In the traditional setting, the term simply means a freeborn person of any community; while "citizenship" refers to the status of being a citizen especially of a society or community with all the rights.

Education on the other hand, is a gradual process of learning and development (Ukaegbu 2005). The term "education" could be used in four main senses in which it is seen to connote a process, a product, a discipline and an institution (Obasi et al. 2004). Seen as a process, education represents the conscious activity is either imparting and/or acquiring knowledge or skill or information whether in organized or not so organized way with the intention of bringing about some desired behavioural outcomes in the participant. It encompasses teaching and learning specific knowledge, beliefs and skills (Igbuzor, 2013). In this connection, education here is a social science discipline.

Mokwuonye (1991) defined Citizenship Education as a conscious process of inculcating certain values, habits, skills and attitudes, which the society considers desirable and essential for its survival as a unit and for its development. Kissock (1981) added that Citizenship Education entails any organized programmed, formal or informal that can make the citizen to become more alive to their responsibilities and obligations to themselves, 
fellow human beings and the society at large. According to Dave (2006) the aim of Citizenship Education is to develop young people into responsible citizens. In other words, Citizenship Education will develop in individual attitudes, values and skills that will enable them to participate actively in society.

The United Nations says youth are those within the ages of 15-24 years; while the national youth service corps put it at 18-30 years. The youth policy says they are all young persons of the ages 18-35 years (Igbuzor, 2013). The National Youth Development Policy (2001) defines youth as people aged 18-35.

Restiveness according to Hornby (2000) is being or acting impatiently or being bored. For youth to be in this state means that their energy must be directed to what they feel can occupy them. Youth restiveness is synonymous to youth violence. This shows that youth with this bundle of energy is unwilling to submit to authority. Youth restiveness according to Japa (2011) is seen from the point of view of idleness and impatience which culminate in anti-government and destructive tendencies to destroy social decorum. The strategies often adopted could be in form of verbal outburst, frivolous or inflammatory petitions, demonstrations or carrying of arms to dismantle, disorganize existing idea or destroy life and property, all these constitute youth restiveness. Elegbeleye (2005) defined youth restiveness as "a sustained protestation embarked upon to enforce desired outcome from a constituted authority by an organized body of youths." It is marked by violence and disruption of lawful activities. Mgboh (2017) view youth restiveness as the uncontrolled, violent and unpleasant ways by which youth communicate their dissatisfaction to the government or people in authority over a perceived neglect of their demands and expectations.

\section{Youth Restiveness in Nigeria}

To put the Nigerian society in the right perspective in respect of the values, it is pertinent to highlight some of the qualities, attitudes and virtues which citizens of a country are expected to exhibit if the nation as well as citizens within it are to survive and progress. Such qualities include honesty, tolerance and cooperation; national consciousness, patriotism, obedience to the law and respect for fundamental human rights and freedoms; respect for constituted authority and national symbols, justice and fair play and inter and intra-group activities. The qualities and values listed above are universally adjudged to form the basis for harmonious co-existence and for reducing social friction to the barest minimum (Niyi, 2013).

Unfortunately, the degree of indiscipline in Nigeria today is alarming. Social vices, political and economic crimes prevail and continue to flourish. There is an ever-growing frenzy by members of the public to "make it quick" and by all means. Thus, fraud, open bribery, drug abuse and drug trafficking, armed robbery, smuggling and certificate racketeering are among the heinous crimes growing unabated in our society today. One cannot but add to the list of incessant Fulani herdsmen attacks across the nation, Boko Haram insurgent activities, inter-tribal and religious conflicts which in many cases claims the lives of innocent citizens. The attitude of many Nigerians to civic duties is very negative and vague and their performance fall short of the standard required advancing any country (Niyi, 2013).

The rate of kidnapping in Nigeria today is unacceptable. Few years ago, it started like a joke and grows up to be a threat to the nation's security. Foreigners and foreign workers are withdrawing, and this will tell on investment. The attacks and abduction of expatriates took a negative turn on the economy as oil companies and other foreign companies relocated to other countries that are more peaceful. Political office holders, public servants and wealthy ones from that part of the country are no longer interested in visiting home or their constituencies. This act alone has contributed immensely in crippling the growth and development of the region and the country at large.

The multiplicity of Nigeria federation gave rise to ethnic groups forming association to champion their common course. The country has experienced the proliferation of many restive groups. At the youth level, they form ethnic militias as an aggressive wing to agitate for their interest. In the West they have the Oodua People's Congress (OPC); in the South-East there are Movement for Sovereignty of State of Biafra (MASSOB), the Bakassi Boys; in the North there are the Boko Haram, the Yan Daba boys and the Fulani herdsmen and in the South, there are Egbesu Boys of Africa (EBA), Niger-Delta Volunteer Force, and the Chicoco Movement, the North Central has the OMBATSE and so on (Mohammed, 2012; Mgboh, 2017). These groups claim to represent specific ethnic or communal interests and adopt various tactics including violence in the conduct of their activities and these activities are carried out by the youth. The heights of this restiveness are the activities of Boko Haram and the Herdsmen attack everywhere in Nigeria. These challenges have thrown the country into pandemonium.

The destructions of pipeline in the Niger-Delta area have caused a lot of harm to the people and the economy of the country. It brought about untold hardship to the people and the scarcity has a multiplier effect. The youth are still at the centre of this negative act.

Another worrisome act of the youth is the way and manner they are being mobilized for electoral manipulation in Nigeria. Nigeria has not fared well with all the elections that have been conducted since 1960 till date. The youth are instruments of disruption and are adequately use by the unpopular politicians who are desperate for victory. The various activities of the of the youth during election include snatching of ballot boxes, stuffing of ballot boxes, multiple voting, under-age voting, multiple registration. 
Japa (2015) added that the activities of cult members on campuses have grave implication for national unity and development. The activities of these cult members create tension, disruption of academic programmes, loss of lives and properties especially during clashes by opposing rival cult members.

\section{Causes of youth restiveness}

Lack of Good Governance: Good governance is a system where by society's resources is been managed transparently with accountability as well as given room for popular participation in governance among others by responsible leaders (Aro, 2011: 160). Sadly, in Nigeria bad governance is more typical than good. The mentality of the leaders, their programmes, projects and implementation policies did not give any hope to the youths but, bringing about disjointed development. Accordingly, most of the youths are disappointed and lost hope on what the future holds for them. The young being vigorous, unemployed, baffled, and irate searching for where to direct their stored energy, vitality promptly seize any brutal circumstance that offers them practical chance of getting ready, to consume the heaped-up vitality and vent out their pleasure of the societal disregard on them (Anasi, 2010). The government should likewise bear a significant part of the fault for their non-execution throughout the years, coming full circle in disregard of agriculture, epileptic power supply, corruption and insensitive to the situation of the populace. The researcher observes that the inability of the Nigerian government to consciously manage public resources entrusted on them for people's interest have contributed greatly to the spread of youth restiveness in Nigeria. If these entrusted resources have been used for the benefit of the whole Nigerians, youth would not be available for easy inducement for insurgency or terrorism.

Lack of proper upbringing: Many of the youth's deviant behaviour and restive attitude are due to poor or absence of proper home upbringing. Many lacked the close contact with their working class and busy business parents. Most children were left under nannies and relatives.

Parents are no longer committed to the preparation of their youngsters because of the struggle to make ends meet. Youngsters are currently left to their own whims and caprices while the older folks observe vulnerably as adolescents execute all way of wrongdoing. The family and societal values, norms, traditions and culture were not properly inculcated. They were exposed wrongly; some of them engaged in unimaginable deviant behaviours like drug abuse and addiction, prostitution, cultism, armed robbery and so on.

Corruption: Nigeria is globally recognised as one the most corrupt countries in the world. The country is blessed with abundant natural and human resources, but mismanagement from those piloting the affairs of the country has thrown the country into more troubles. The level of corruption greatly weakens the strands of trust between the state and the masses. Nigeria is ranked 139th out of 176 countries in Transparency International's 2012 corruption perceptions Index, by this implication the 35th most corrupt country in the world (TI, 2012). For instance, some argued that "there are so many symptoms of corruption and that corruption are killing Nigeria, a slow, painful death" (James and Jennifer, 2011). Throughout the country, there are myriad examples of what John Alexander described as the "concentration of wealth and power in the hands of a very few, with nepotism and tribalism as key factors (Imaji; Ranjit-Singh and Muhammad, 2015). The money budgeted for infrastructural development of the country was embezzled, the money meant for the fight against the Boko Haram insurgency was diverted for other personal use by those saddled with the responsibilities taking care of the Nigeria forces. This mismanagement of the public funds had made many children orphans and women made widows because of lack of weapon to fight the insurgencies.

There is a connection between corruption and youth restiveness. Corruption delegitimizes the state and breaks the relationship between government (state) and the people (society). Corruption of state officials undermines the rule of law and the authority of the state, thereby leading to hostility by citizens who came to view the state as an "enemy". In such a case, the citizens result to self-help and use violence as means asking for their right.

Poverty: Poverty suggests disparity and unfairness, and this is injurious to the poor. More than 70 percent of individuals in Nigeria are in in abject poverty, living below the poverty line, and 33\% live under a US dollar daily (Zakaria, 2006). This figure incorporates a multitude of youth in urban areas who are struggling to make ends meet by hawking petty items in the road. The deals per-day and the overall revenue on such merchandise are small to the point that they can barely live above the poverty line. Disappointed, baffled, and dejected, they look for a chance to express their resentment against the state. Aworawo (2000) and Zakaria (2006) concurred that there is a nexus between poverty, loss of means of livelihood, imbalance, and youth fretfulness as prove by the various vicious challenges against the wielders of power in Nigeria.

Unemployment: Unemployment is a hydra-headed beast which exists among the youth in most developing nation. Experts conclude that the quantity of jobless youth is twice as high as official figure. Ozohu-Suleiman (2006) notes Nigerian youth are trapped by unemployment. Zakaria (2006) believes that "the rising tide of unemployment and the fear of a bleak future among the youth in African countries have made them vulnerable to the manipulations of agents' provocateurs". These include aggrieved politicians, religious demagogues, and greedy multinationals that employ these youths to achieve their selfish ambitions. Aduba (2019) opines in a country with 72 public universities, 45 private ones, 45 polytechnics and 37 colleges of education, it is regrettable that unemployment is 
prevalent. Most of the graduates are unemployable and they have continued to saturate the labour market on a yearly basis. An educational system that cannot produce self-employed graduates must be basically defective. Zakaria (2006) strongly believes that the absence of job opportunities in developing countries is responsible for youth restiveness with disastrous consequences.

Peer Group Influence: Peer group influence cannot be overemphasized as one of the causes of youth restiveness. The youths are obsessed with accessing pornographic websites online, cyber-crime (yahoo-yahoo), membership of secret cults, smoking, drug abuse and addiction, drinking, fornicating, partying and for the most part being wild. Academic excellence at school is presently a relic of past times. The criteria for measuring success for youth today incorporates the above-listed social vices. Most of the youths engage in criminal acts to achieve a millionaire status, this has led to apathy in many genuine way of life and try to make money either by hook or by crook means.

The role of the elders: Most of the older folks carry on with a questionable life and work with no ethical code. The young are keenly watching as open assets are redirected into private accounts, cash for project constructions are collected and work left undone, ghost workers are paid, employments sold like commodities in the market, fraudsters are celebrated, known lawbreakers and criminals are praised in the society and some segments of the nation are alienated while others are favoured maximally with assets that belong to all. The youths are likewise mindful that only few members of the population are controlling all the nation's wealth.

\section{The Role of Citizenship Education in Curbing Youth Restiveness}

Education is a potent instrument that can be used to foster peace and unity. Therefore, we should evolve a type of education that will inculcate in the learners the ideal of national consciousness and awareness. Citizenship education should be introduced at all levels of our educational system. Iyamu (1999) defines citizenship education as a conscious effort to inculcate in the youth, a set of values and attitude contingent on the need and problems of the society. To Osakwe (1993), citizenship education conveys to the learners, the body of knowledge, set of values and behavioural orientation that are considered vital and necessary for the sustenance and well being of the people.

Citizenship education has a positive and decisive role to play in curbing youth restiveness in Nigeria, taking into cognizance the various factors responsible for youth restiveness. This various restiveness with their attendant consequences leave no one in doubt of the urgent need to have them reduced to the barest minimum through the teaching of citizenship education.

The aim of citizenship classes is to develop young people into responsible citizens, who understand their rights and responsibilities and can play an active part in society. In other words, citizenship education requires a citizen to be well informed, gather facts, reject ethnocentrism, religious jingoism and encourage national consciousness. That means that citizenship education will develop in individual skills, attitudes and values that will enable them to show concern for the wellbeing and dignity of others, respecting the worth of others and approaching civil decision in a rational manner.

The knowledge of citizenship education enables learners to think beyond their individual and ethnic interests; thereby making them to tolerate and respect the views of others. It is citizenship education that will enhance unity and stability and human right. According to Yusuf (2005), citizenship education which has as important components of value education could serve as an instrument for bringing about desirable positive change in the Nigerian value orientation. It determines action and shapes the direction in which an individual operates in a given situation.

There is also the need to acquire the right type of attitude to work that will serve as a guild as we interact with people and events in the world (Eyo, 1995). In other words, Nigerians must adopt the right type of attitude and shun corrupt behaviours like advanced free fraud and cultivate the attitude of dignity in labour. Nigerians must also see themselves as their brothers' keeper. The need for national unity and stability is greater now in Nigeria, in the wake of crisis in the North-East and Fulani Herdsmen attacks. Many Nigerian youths are now enrolling as political thugs and kidnappers. Citizenship Education should be given to youths, the type that inculcates moral values, the type that will help raise their civil consciousness and help develop appropriate social values and attributes for effective participation in society (Mohammed, 2012).

The National Policy on Education (2004) also outlines some of the virtues to be derived by entrenching citizenship education in schools namely; a display of shared responsibility for the common good of society cherishing a sense of respect and tolerance for others by individuals; and a cultivation of social attitudes, trustworthiness, diligence and obedience. But today, the herdsmen attack, Boko Haram insurgence, crises in the Niger-Delta and activities of youth restiveness indicate that little success in this regard is being made. It has therefore, become possible to establish here that a great link exists between human behaviour and endeavour with the orientation and thinking pattern embedded in citizenship education. Thus, effective exploration of citizenship virtues and characteristic intrinsic in schools could go a long way towards addressing the issues associated with youth restiveness in the Nigerian society for effective governance and national sustainability (Irmiya, 2009). 


\section{Conclusion}

There is no gain saying that every country that have become economically viable and political stable did not achieve the fit without having adequate programmes and policies for the youth. Youths all over the world are vital and important segment of the society in which they live. For Nigeria to realize its dream, she needs to give keen attention and sense of responsibility to the youth. They constitute the greater percentage of the population and the fulcrum of the labour market. It is important to remould the youth for the good of the country and peaceful coexistence of its populace. The future belongs to youth who make productive use of information and knowledge. With adequate citizenship education that focuses and promotes social order in the society, Nigerian youth will achieve their potential and participate actively in local and international affairs in a manner that eschews violence. The youth must be taught the virtues of hard work and earning honest living through work.

\section{Recommendations}

From the foregoing, it is crystal clear that citizenship education is a potent tool for curbing restiveness among our youths in Nigeria. It is against this background that the following recommendations are made:

1. The family as the first agent of socialization has a great role to play in proper upbringing of their children. The first teacher of every child is the parent and it is expected that the parent must inculcate in the child values, culture and norms that are significant for the development of the country.

2. The government has a significant role to play in curbing restiveness by creating job opportunity for the youths. Joblessness is the main reason for recruiting youths for political thuggery and if this can be combated by job creation or creating conducive atmosphere for individual investment, it will reduce restiveness in Nigeria. When the active and adventurous mind of the youth is not meaningfully engaged, it engages itself.

3. Citizenship education should be introduced at all level of the training institutions (primary to university level). This is because teachers must be prepared and equipped to effect the needed change from childhood to adulthood.

4. There must be pro-active value re-orientation of the youths through counselling and public enlightenment.

5. The issue of governmental policies and programmes must be implemented to the latter and the youth must be the centrepiece.

\section{References}

Aduba, I. (2019). Youth restiveness in Nigeria, who is to blame? The Pointer, January 4.

Anasi, S. N. I. (2010). Curbing Youth Restiveness in Nigeria: The Role of Information and Libraries. Library Philosophy and Practice (e-journal). http://digitalcommons.unl.edu/libphilprac/388

Aworawo, D. (2000). Mal-distribution and poverty as factors in the crisis of the Nigeria state. The Constitution: A Journal of Constitutional Development 1 (2): 1-13.

Aro, O. I. (2011). Economic Empowerment in Nigeria: Yesterday, Today and Tomorrow, International Journal of Humanities. 3 (1), $160-167$.

Dave, H. C. (2006). Citizenship lesson inadequate. BBC News on Wednesday, 27 September.

Elegbeleye, O.S. (2005). Recreational facilities in schools: A panacea for youths' restiveness. Journal of Human Ecology 18 (2): 93-98

Eyo, I. (1995). Social issues in Nigeria: A psychological analysis. Enugu: Auto century Publishers.

Federal Government of Nigeria (2001). National Youth Policy. Available: http://www.thepresidency.gov.za/docs/policy/national_ youth _ policy.pdf

Federal Republic of Nigeria (2004). National policy on education. Lagos: NDRC Press.

Hornby, A.S. (2000). Oxford advanced learners dictionary of current English 6th Edition. London: Oxford University Press.

Igbuzor, (2013). Galvanizing the youth to sustain good leadership. Retrieved on $21^{\text {st }}$ February, 2018 from otiveigbuzor.com/wp-content/uploads.

Imaji, Z.O.S., Ranjit Singh, D.S. \& Muhammad F.O. (2015). Governance and Boko Haram Insurgence in Nigeria: An analysis. Academic Journal of Interdisciplinary Studies. 4(2), 35-44.

Irmiya, R. A. (2009). Towards combating youth restiveness for a sustainable democratic Nigeria through citizenship education. NASHERJ. 7(1), 166-172.

lyamu, E. O. S (1999). Citizenship education in Nigeria schools. Rationale and constraints. Nigeria Journal of social educators. 2(1)35-51

James, J.F.F \& Jenifer G. (2011).Terrorism and Political Violence in Africa; Contemporary Trends in a Shifting terrain. Perspective on Terrorism A Journal of the Research Initiative. $\mathrm{http} / / \mathrm{www}$. terrorismanalysts.com/pt/index,5 (3-4), 63-80.

Japa, M. I. (2011). Youth restiveness and internal security in Ebiraland. NASHERJ, 9(2), 202-206

Japa, M. I. (2015). Curbing youth restiveness in Nigeria through functional citizenship education. Knowledge 
review, 33(3) 192-197.

Kissock, A. (1981). The role of social studies in re-ordering Nigeria Value. Nigeria Journal of social studies 4(1), 48-53

Mgboh, G. (2017). Combating youth restiveness in Nigeria. The Tide. www.thetidenewsonline.com2017/03/03/combating-youth-restiveness-in-nigeria/ accessed on 18/02/2019

Mohammed, M. (2012). The role of citizenship education in fostering unity in Nigeria. Belt journal of Education in Nigeria, 3(1), 260-266.

Mokwuonye, U. (1991). Value education in Iyamu, E. and Onyesom, L. (FDS) readings in social studies I. Benin City: Okilo. 111-123.

Niyi, E. (2013). Federal Government to empower 6 million youths. Retrieved 22 $2^{\text {nd }}$ January 2018. From www.information.com $/ 2013 / 08 / \mathrm{html}$

Obasi E. et al. (2004:5-20), Citizenship Education for Nigerian Student in Tertiary Education, New Vision Publishers, Owerri.

Osakwe, E.O (1993). Citizenship education: The Habit of social studies. Nigeria Journal of social studies review 2(1)

Ozohu-Suleiman, A. (2006). The Nigerian youth in contemporary political development: Relevance, challenges, and role expectation. The Constitution: A Journal of Constitutional Development 6 (4): 97-111.

Transparency International TI,(2012). Corruption Perception Index. http://tranparency.org/country. Sunday Trust, Sunday 9 September

Ukaegbu F. N. (2005). The Igbos: The Afrikan Root of Nations. Ibadan: Heinemann Educational Books

Yusuf. A. (2005). The effect of cooperative instructional strategy on student's performance in Junior Secondary School social studies in Ilorin, Nigeria.

Nigerian Journal of Social Studies, viii (1\&2), 23- 36.

Zakaria, Y. (2006). Youth, conflict, security, and development. Available: http://www.realityofaid.org/roareport.php?table $=$ roa2006\&id $=6$ 